RESEARCH NOTE

\section{Nematode Parasites of Brazilian Accipitrid and Falconid Birds (Falconiformes)}

\author{
Roberto Magalhães Pinto ${ }^{+}$, J Júlio \\ Vicente, Dely Noronha
}

\begin{abstract}
Departamento de Helmintologia, Instituto Oswaldo Cruz, Av. Brasil 4365, 21045-900 Rio de Janeiro, RJ, Brasil
\end{abstract}

Key words: nematodes - synonymy - Falconiformes birds - Brazil

This survey was scheduled to add recent data on nematode parasites of Brazilian hawks, in a study regarding avian helminths.

Sixty-five samples of nematodes recovered from Brazilian hawks between 1920 and 1955 in north, southeastern, and mid-eastern regions and deposited in the Helminthological Collection of the Oswaldo Cruz Institute (CHIOC) were studied. The number of samples according to each family of host species is:

ACCIPITRIDAE: 6 from Accipiter bicolor pileatus (Temmink); 1 from Busarellus $n$. nigricollis (Latham); 1 from Buteo magnirostris magniplumis (Bertoni); 12 from Buteo m. magnirostris (Gmelin); 4 from Buteo magnirostris nattereri (Sclater \& Salvin); 3 from Buteogallus u. urubitinga (Gmelin); 2 from Gampsonix s. swainsonii (Vigors); 4 from Geranospiza $c$. caerulescens (Vieillot); 1 from Harpagus diodon (Temminck); 8 from Heterospizias m. meridionalis (Latham); 1 from Ictinia plumbea (Gmelin); and 2 from Rostrhamus s. sociabilis (Vieillot); FALCONIDAE: 1 from Falco $f$. femoralis (Temminck); 1 from Falco r. rufigularis (Daudin); 1 from Falco sparverius cearae (Cory); 1 from Falco sparverius connamominus (Swainson); 2 from Herpethoteres c. cachinnans (L.); 6 from Milvago c. chimachima (Vieillot); 3 from Polyborus p. plancus (Miller) and 5 from Polyborus sp.

Nematodes were fixed in Railliet \& Henry's solution, and were processed for study as de-

\footnotetext{
+ CNPq research fellow Proc. n 300374/80-1

Received 17 January 1994

Accepted 29 April 1994
}

scribed elsewhere (RM Pinto et al. $1993 \mathrm{Mem}$ Inst Oswaldo Cruz 88: 279-284). NHR and NGD indicate New Host Record and New Geographical Distribution, respectively. Classification and common names of hosts follow OMO Pinto (1978 Novo catálogo das aves do Brasil 1, 446 pp) and H Sick (1984 Ornitologia Brasileira, uma introdução 1, 474 pp). Confirmation of the taxonomic status of the nematodes was based on G Hartwich (1974 CIH Keys to the nematode parasites of vertebrates 2: 1-15), AG Chabaud (1975 idem 3:1-58), and RC Anderson and $O$ Bain (1976 ibidem: 59-116).

Contracaecum caballeroi Bravo-Hollis, 1939

(Ascaridoidea, Anisakidae, Anisakinae)

Hosts: Buteo m. magnirostris (Gmelin) (-Rupornis magnirostris); common name: roadside hawk ("indaié")-NHR; Buteogallus u. urubitinga (Gmelin) (=Falco urubitinga, Hypomorphnus urubitinga); common name: black hawk, zone-tailed hawk ("cã-cã, cauã, gavião preto"); Falco sparverius cearae (Cory) (-Cerchneis sparverius cearae); common name: American krestel ("gaviāozinho")-NHR; Herpetotheres c. cachinans (L.); common name: laughing falcon ("acauã")-NHR; Milvago $c$. chimachima (Vieillot); common name: yellowheaded caracara ("cará-cará-i, cará-cará-pinhé, pinhé, gaviāo carrapateiro, chimango branco")NHR.

Site of infection: intestine.

Localities: Porto Cabral, State of São Paulo, Barranco Alto and Porto Esperança, State of Mato Grosso do Sul, Brazil - NGD.

Specimens studied: CHIOC no 33087 a-c, 33093 a-b (whole mounts); 8671, 8768, 15520 (wet material).

Our specimens were identified as those previously redescribed (H Lent \& JFT Freitas 1948 Mem Inst Oswaldo Cruz 46: 1-71), considering the size of the spicules and comparison of length ratios regarding esophagus, esophageal cecum and ventriculus. This is the first record of the genus Contracaecum in Brazilian Falconiformes.

Physaloptera acuticauda Molin, 1860

(Physalopteroidea, Physalopteridae,

Physalopterinae)

Hosts: Accipiter bicolor pileatus (Temmink) (-Falco pileatus, Odontriorchis pileatus); common name: bicolor hawk ("gavião-caçador bicolor")-NHR; Herpetotheres $c$. cachinans.

Sites of infection: stomach and intestine.

Localities: Barranco Alto and Salobra, State of Mato Grosso do Sul, Brazil.

Specimens studied: CHIOC no 33074, 33099 a-b (whole mounts). 
Physaloptera alata Rudolphi, 1819

Hosts: Buteo magnirostris magniplumis (Bertoni) (-Rupornis magnirostris magniplumis); common name: roadside hawk ("gaviāo pegapinto, gaviāo carijó, indaié")-NHR; Buteo m. magnirostris-NHR, Herpetotheres c. cachinans.

Sites of infection: stomach and intestine.

Localities: Barranco Alto, Bodoquena and Salobra, State of Mato Grosso do Sul, BrazilNGD.

Specimens studied: CHIOC no 33,084, 33,085, 33,098 (whole mounts), 13,174 (wet material).

This species has been referred in a wide range of Falconiformes hosts in several parts of the world (EB Cram 1927 US Nat Mus Bull 140:1465; BB Morgan 1943 Trans Amer Micr Soc 62: 72-80) and this is the first report of $P$. alata in Brazil.

\section{Physaloptera subalata Schneider, 1866}

Hosts: Accipiter bicolor pileatus-NHR; Geranospiza c. caerulescens (Vieillot); common name: grey crane hawk ("gaviãozinho-pernilongo")-NHR.

Sites of infection: esophagus and stomach.

Localities: Barranco Alto and Salobra, State of Mato Grosso do Sul; Manaus, State of Amazonas, Brazil.

Specimens studied: CHIOC no 33075 a-f, 33076 a-c, 33097 a-b (whole mounts); 12617, 15601,21472 (wet material).

Oxyspirura (Cramispirura) altensis (Rodrigues, 1962)

Skrjabin, Sobolev \& Ivaschkin, 1967

(Thelazioidea, Thelaziidae, Oxyspirurinae)

Host: Heterospizias m. meridionalis (Latham); common names: brown buzzard, savannah hawk ("gaviāo-caboclo, casca de couro, inhapacanim do campo")-NHR.

Site of infection: eyes.

Locality: Barranco Alto, State of Mato Grosso do Sul, Brazil.

Specimens studied: CHIOC no 33070, 33071 (whole mounts).

Some differences were detected in the male specimen presently studied, when compared to those of the original description: presence of a gubernaculum, greater number of precloacal papillae and the aspect of the spicules; however, in our opinion, these modifications may be related to a parasite/host adaptation process. In order to properly compare both samples, type specimens of $O$. (C.) altensis deposited in CHIOC no. 28748 a-b, 28749 a-b (whole mounts) were examined.

Thelazia (Thelaziella) aquilina Baylis, 1934 (Thelazioidea, Thelaziidae, Thelaziinae)
Hosts: Accipiter bicolor pileatus-NHR; Buteogallus u. urubitinga-NHR; Milvago $c$. chimachima-NHR; Polyborus p. plancus (Miller); common name: crested caracara ("carácará, carancho")-NHR.

Site of infection: eyes.

Localities: Barranco Alto and Salobra, State of Mato Grosso do Sul, Brazil.

Specimens studied: CHIOC no 33073, 33077 (whole mounts); 15078, 15502 (wet material).

This is the second report of this species in Brazil and in new hosts, taking into account that Thelazia spizaeti was proposed (AA Strachan 1957 Can J Zool 35: 179-187) from a Brazilian hawk Spizaetus o. ornatus (Daudin) and later, the species was restudied on basis on type material and considered a junior synonym of $T$. aquilina (RC Anderson \& C Diaz-Ungria $1959 \mathrm{Mem}$ Soc Ci Nat La Salle 19: 35-37).

Procyrnea leptoptera (Rudolphi, 1819) Chabaud, 1975

(Habronematoidea, Habronematidae,

Habronematinae)

Hosts: Buteo m. magnirostris-NHR; Buteo magnirostris nattereri (Sclater \& Salvin) (-Asturina nattereri); common name: hawk ("gaviāo pega-pinto")-NHR; Falco sparverius cearaeNHR; Geranospiza c. caerulescens-NHR; Harpagus diodon (Temminck); common name: rufous-thighed kite ("gaviāo cinza")-NHR; Heterospizias m. meridionalis-NHR; Milvago $c$. chimachima-NHR; Polyborus p. plancus-NHR.

Site of infection: gizzard.

Localities: Belém, State of Pará; Bodoquena and Salobra, State of Mato Grosso do Sul, BrazilNGD.

Specimens studied: CHIOC no 33079 a-b, 33082,33086 a-c, 33088, 33090 a-g, 33095 (whole mounts); 3300, 8681, 11676, 11677, $11692,12517,12618,13172,13182,13483$, 13485,15020 (wet material).

This is the first report in Brazil of $P$. leptoptera, the type of the genus, previously assignaled in several hawks from Europe and Africa as Habronema leptoptera ( Cram loc. cit.). 1975

Procyrnea mansioni (Seurat, 1914) Chabaud,

Host: Buteo m. magnirostris-NHR.

Site of infection: gizzard.

Locality: Salobra, State of Mato Grosso do Sul, Brazil.

Specimens studied: CHIOC no 33078 a-c, 33081 a-c, 33083 a-b (whole mounts).

This species was referred in Brazil as Spiroptera longistriata ( $\mathrm{R}$ Molin 1859 Sitzungsb $d k$ Akad d Wissench Wien math-naturw C 1 (1858)33: 297-302). According to LG Seurat (1914 C r Soc Biol Paris 76: 7-10), part of 
Molin's material should be described as a new species, Habronema mansioni, proposed at that occasion. In a same necropsy, $P$. mansioni was found together $P$. Longistriata and this situation can be related to a possible misinterpretation of Molin, when dealing with two distinct species instead of only $P$. longistriata as formerly stated.

Synhimantus (Synhimantus) rectus (Molin, 1860) Gendre, 1920

(-Synhimantus (S.) sygmoideus Molin, 1860) Skrjabin, 1924)

(Acuarioidea, Acuariidae, Acuariinae)

Hosts: Buteo m. magnirostris-NHR; Buteo magnirostris nattereri-NHR; Heterospizias $m$. meridionalis-NHR; Milvago c. chimachimaNHR.

Site of infection: gizzard.

Localities: Angra dos Reis and Rio de Janeiro, State of Rio de Janeiro; Salobra, State of Mato Grosso do Sul, Brazil.

Specimens studied: CHIOC no 33080, 33091 a-h, 33092, 33096 a-d (whole mounts); 4183, 7691 (wet material)

The junior synonymy proposed herein, considering $S$. (S.) sygmoideus identical to $S$. (S.) rectus, the valid species, is based on the fact that data concerning morphometrics, hosts and geographical distribution on both species are coincidental. Moreover, the character that has been taken into account to distinguish $S$. (S.) sygmoideus from $S$. (S.) rectus refers only to the aspect of the body in the former, described as "bent in a sigmoid curvature". In the several samples examined, some specimens from the same necropsy, either appeared properly straight or were somewhat bent, indicating that this difference in aspect may be related to the individual absorption of the fixative solution.

Skrjabinura spiralis Gnédina, 1933 (-S. magnum Johnston \& Mawson, 1941) Mawson, 1960)

(Seuratoidea, Seuratidae, Seuratinae)

Hosts: Falco r. rufigularis Daudin (-Falco albigularis); common name: bat falcon ("gavião de coleira, caure, tentenzinho")-NHR; Milvago c. chimachima-NHR.

Site of infection: intestine.

Locality: Salobra, State of Mato Grosso do Sul, Brazil.

Specimens studied: CHIOC no 33094 a-b (whole mounts), 11539 (wet material).

This is the second report of $S$. spiralis in Brazil, already referred in a guira cuckoo, Guira guira (Gmelin), based on a single male specimen (SS Rodrigues \& HO Rodrigues 1981 Alas Soc Biol Rio de Janeiro 22: 39-56). In this opportunity, S. magnum (Johnston \& Mawson, 1941)
Mawson 1960, is proposed as a junior synonym of $S$. spiralis. The genus Seuratinema was erected (TH Johnston \& PM Mawson 1941 Proc Linn Soc $N$ South Wales 66: 250-256) to include $S$. magnum as the type species, based on a single female specimen. The synonymy of the genus Seuratinema with Skrjabinura was proposed (PM Mawson 1960 Ann Par hum comp 35: 430-431), and this concept was ractified by AG Chabaud (1978 CHI Keys to the nematode parasites of vertebrates 6: 1-71), who also referred to the mistake of Mawson (1960), when reporting Skrjabinema instead of Skrjabinura, which is the concerned genus. Comparison of original morphometric data on $S$. spiralis according to MP Gnédina (1933 Ann Par 11: 180-184) and Johnston and Mawson (loc. cit.) with those of the present findings, supports the synonymy proposed herein. 1919

Diplotriaena falconis (Connal, 1912) Blanc,

(Diplotriaenoidea, Diplotriaenidae,

Diplotriaeninae)

Host: Polyborus p. plancus.

Site of infection: body cavity.

Locality: Salobra, State of Mato Grosso do Sul, Brazil.

Specimen studied: CHIOC no 15099 (wet material).

Specimens which could not be identified to the already referred species, due to their poor conditions of preservation are distributed in the following genera:

\section{Contracaecum sp.}

Hosts: Busarellus n. nigricollis (Latham); common name: black collared hawk ("gaviāo velho, gaviāo padre, gavião belo, panema"); Polyborus sp., Rostrhamus s. sociabilis (Vieillot); common name: snail kite ("gaviāo-caramujeiro, gaviāo de aruá").

Sites of infection: intestine and stomach (?).

Localities: Barranco Alto and Salobra, State of Mato Grosso do Sul; Lassance, State of Minas Gerais, Brazil.

Specimens studied: CHIOC no 8095,8146 , $8162,8689,8695,141 ! 2,14969,15548$ (wet material).

\section{Physaloptera sp.}

Hosts: Gampsonix s. swainsonii Vigors; common names: Vigor's hawk, pearl kite ("gaviāozinho"); Ictinia plumbea (Gmelin); common name: plumbeous kite ("sovi, gaviāo sauveiro").

Site of infection: stomach.

Locality: Salobra, State of Mato Grosso do Sul, Brazil.

Specimens studied: CHIOC no 12630,12988 , 20504 (wet material). 
Oxyspirura sp.

Hosts: Falco f. femoralis Temminck (- Falco fuscocaerulescens); common name: aplomado falcon ("gavião de coleira"); Heterospizias m. meridionalis.

Site of infection: eyes.

Localities: Cachimbo, State of Pará; Salobra, State of Mato Grosso, Brazil.

Specimens studied: CHIOC no 33072 (whole mount), 11675, 12526 (wet material).

\section{Procyrnea sp.}

Hosts: Falco sparverius connamonimus Swainson; common name: American krestel ("gaviãozinho"); Polyborus sp.

Site of infection: gizzard.

Localities: Lassance, State of Minas Gerais; Rincão, State of São Paulo, Brazil.

Specimens studied: CHIOC no 2008, 6164 (wet material).

Other nematode species reported from hawks in Brazil and not found during the present study:

Dispharynx capitata (Molin, 1860) Cram,
1927, from Accipiter s. superciliosus (L.) (-Falco minutus); Oxyspirura octopapillata Caballero, 1942, from Accipitridae sp;; Physaloptera inflata (Molin, 1860) Stossich, 1889, from Parabuteo u. unicinctus (Temminck); Physaloptera losseni Ortlepp, 1937, from Leptodon forbesi (Swann, 1922); Thelazia campanulata (Molin, 1858) Railliet \& Henry, 1910 (species inquirenda), from Buteo m. magnirostris (Gmelin), Falconidae sp.; Thelazia papillosa (Molin, 1860) Railliet \& Henry, 1910 (species inquirenda) from Geranospiza caerulescens gracilis (Temminck); Thelazia pittae Johnston \& Mawson, 1941 (species inquirenda), from Spizastur melanoleuchus (Vieillot); Serratospiculum verrucosum (Molin, 1858) Skrjabin, 1915, from Buteo swainsoni Bonaparte; Spiroptera saginata (Rudolphi, 1819) Dujardin, 1845, from Falco furca-tus(sic)(RJ Ortlepp 1922 Proc Zool Soc London 2: 9991107, Cram (loc. cit.), Strachan (loc. cit.), Anderson \& Diaz-Ungria (loc. cit.), S Ya-maguti 1961 Systema Helminthum 3. The nema-todes of vertebrates I, II, 1261 pp, CP Santos \& DC Gomes 1989 Rev Brasil Biol 49: 1031-1034). 